\title{
Rancang Bangun Aplikasi e-CRM Alfamart Batam Dengan Metode Extreme Programming
}

\author{
Tukino \\ Universitas Putera Batam, Jl. R. Soeprapto Mukakuning, Batam 29434, Indonesia
}

\begin{tabular}{l} 
KEYWORDS \\
\hline Web-based Customer Relationship \\
Management Information System
\end{tabular}

\section{CORRESPONDENCE}

Phone: +6281364813278

E-mail: mas.kino@gmail.com

\section{PENDAHULUAN}

Perkembangan ilmu pengetahuan khususnya teknologi informasi telah mengalami perkembangan yang sangat pesat saat ini. Salah satunya perkembangan teknologi informasi disertai dengan internet, yang melahirkan konsep teknologi informasi berbasis web yang banyak dikembangkan dalam bisnis perusahaan diberbagai bidang. Teknologi informasi dapat digunakan dalam mengelola informasi yang ada didalam perusahaan, baik dari segi karyawan, kualitas produk maupun dari pelayanan pelanggan. Pengelolaan sistem informasi secara efektif dalam perusahaan sangatlah penting karna dapat menjadi dasar untuk memperoleh keunggulan kompetitif. Oleh karena itu, banyak perusahaan yang mulai mengembangkan dan memberikan perhatian khusus pada sistem informasi sebagai sumber informasi secara efektif.

Disamping menawarkan kualiatas produk yang bagus, perusahaan juga harus memperhatikan kualitas layanannya. Kualitas layanan merupakan suatu hal yang sangat penting dalam menghadapi pelanggan yang membutuhkan perhatian dan layanan yang tinggi. Pelayanan yang bermutu tinggi dapat memberikan keselarasan terhadap kebutuhan pelanggan. Pelanggan merupakan salah satu aset yang sangat berperan penting dalam pencapain tujuan dari sebuah perusahaan. Dengan memanfaatkan teknologi informasi berbasis internet perusahaan bisa mengembangkan suatu sistem yang bisa berhubungan langsung dengan pelanggan, sistem ini lebih dikenal dengan Customer Relationship Management (CRM).
Customer Relationship Management (CRM) pada dasarnya merupakan kolaborasi dengan setiap konsumen yang menciptakan keadaan yang tidak merugikan bagi kedua pihak. Dalam perusahaan, Customer Relationship Management (CRM) digunakan sebagai sarana penghubung antara pelanggan dengan perusahaan. Melalui Customer Relationship Management (CRM) perusahaan akan lebih mengetahui apa yang diinginkan pelanggan, apa yang meraka keluhkan, bagaimana competitor terhadap produk atau jasa perusahaan, serta kegiatan member lainnya.

Customer Relationship Management (CRM) dengan dukungan Teknologi Informasi membantu perusahaan untuk memberikan pelayanan yang terbaik bagi pelanggan sehingga pelanggan merasa puas. Customer Relationship Management (CRM) secara umum digunakan untuk membantu kegiatan disales, marketing, dan customer service.

Menyediakan pelayanan kepada pelanggan secara real time dengan menjalin hubungan dengan setiap pelanggan yang berharga melalui penggunaan informasi pelanggan mendukung terbentuknya sebuah sistem Customer Relationship Management (CRM) dalam sebuah perusahaan. Berdasarkan apa yang diketahui pelanggan, perusahaan dapat membuat variasi penawaran, program, pesan, media dan terutama pelayanan. Dalam penerapannya, sistem Customer Relationship Management (CRM) dalam perusahaan membentuk hubungan yang lebih dekat dengan pelanggan, dimana perusahaan dapat mengetahui kebutuhan pelanggan dan menyediakan pilihan produk atau layanan yang sesuai dengan permintaan mereka. Dengan Customer Relationship Management (CRM) memungkinkan terjadinya komunikasi global, sehingga pihak 
perusahaan dan pelanggan dapat menjaring calon pelanggan dengan melalui strategi kepuasan pelanggan. Apliakasi Customer Relationship Management (CRM) dapat mempercepat proses pengolahan data, proses penyimpanan data, proses pencarian data, dan hasilnya lebih akurat sehingga dapat digunakan dan diakses pada saat diperlukan sekarang maupun masa yang akan datang.

PT Sumber Alfaria Trijaya Tbk (Indomaret) Batam, merupakan perusahaan retail minimarket yang terkemuka diseluruh Indonesia. Selain menjadi perusahan retail yang terkemuka di Indonesia yang menjual produk yang berkualitas, perusahaan juga sangat memperhatikan pelayanan terhadap pelanggan yang setiap kali datang dan berbelanja di tokonya. Memperhatikan pelanggan tentu harus memikirkan jenis pelayanan kepada pelanggan, baik itu dari segi kenyamanan, informasi mengenai produk yang dipasarkan, serta kecepatan respon pelayanan yang menimbulkan kepercayaan dari pelanggan.

Sebagai perusahaan retail yang terus berkembang PT Sumber Alfaria Trijaya Tbk (Indomaret) Batam harus tetap mempertahankan kontinuitas usahanya dan berusaha mencari peluang dengan memanfaatkan keunggulan yang dimiliki oleh perusahaan agar mereka tetap bertahan diusaha ini. Salah satu cara yang dapat ditempuh oleh perusahaan dalam membangun loyalitas pelanggan dengan mempertahankan pelanggan yang ada, sehingga mereka loyal dan tidak pindah kepesaing lainnya. Tentunya, itu merupakan tantangan baru bagi perusahaan untuk mengelola aset-asetnya terutama pelanggan. Namun, pelayanan terhadap pelanggan saat ini masih belum begitu maksimal dikarnakan media penyampaian keluhan pelanggan yang masih berbasis telphone, e-mail dan sms customer service serta dua media sosial seperti twitter dan facebook. Penyampaian keluhan melalui media telphone dan sms masih memberatkan biaya pada pelanggan, dan $e$-mail yang masih kurang dikenali oleh masyarakat awam. Untuk penyampaian masalah melalui media sosial seperti twitter dan facebook ini akan banyak mengundang pihak-pihak yang tidak bertanggung jawab untuk mencemarkan nama perusahaan karena sosial media yang digunakan bersifat public. Masalah lainnya, penyampain keluhan pelanggan biasanya hanya disampaikan kepada karyawan yang ada di toko dan jarang sekali keluhan pelanggan disampaikan ke perusahaan pusat. Dengan demikian palayanan terhadap pelanggan tidak begitu memuaskan dan akan mengakibatkan berkurangnya atau hilangnya kepercayaan pelanggan terhadap perusahaan. Oleh karena itu, PT Sumber Alfaria Trijaya Tbk (Indomaret) Batam disarankan untuk mempunyai suatu aplikasi yang dapat mengatur dan memberikan pelayan terhadap keluhan pelanggan tersebut. Sistem informasi Customer Relationship Management (CRM) berbasis web akan dibutuhkan dalam membangun hubungan kepercayaan antara pelanggan dengan perusahaan.

\section{TINJAUAN PUSTAKA}

\section{Pengertian Sistem}

Menurut [5] Sistem adalah kumpulan dari elemen-elemen yang berinteraksi untuk mencapai suatu tujuan tertentu. Elemen Sistem adalah suatu sistem terdiri dari sejumlah elemen yang saling berinteraksi, yang artinya saling kerjasama membentuk satu kesatuan. Sedangkan menurut [6] Sistem adalah sekumpulan elemen yang saling terkait atau terpadu yang dimaksudkan untuk mencapai suatu tujuan.

Untuk menghasilkan suatu sistem yang baik dibutuhkan suatu pengkajian lebih mendalam terhadap sistem tersebut. Suatu sistem bersifat dinamis dan tidak statis, hal ini mengindikasikan bahwa suatu sistem akan selalu berubah dari bentuk yang paling sederhana menuju bentuk yang sempurna. Namun. Untuk mencapai kesempurnaan sistem sangatlah sulit, hal ini karena sistem merupakan bagian-bagian, atau komponen-komponen yang saling melengkapi dan berinteraksi satu sama lainnya untuk mencapai tujuannya [7].

Seperti pendapatnya [1] dalam bukunya Analisis dan Perancangan Sistem Informasi, bahwa sistem adalah: sekelompok elemen-elemen yang terintegrasi dengan maksud yang sama untuk mencapai tujuan. Sumber daya mengalir dari elemen output dan untuk menjamin prosesnya dengan baik maka dihubungkan dengan mekanisme kontrol. Hal ini sejalan dengan pendapatnya [9], menyatakan bahwa suatu sistem terdiri atas objek-objek, atau bagian-bagian, atau komponen - komponen yang berkaitan dan berhubungan satu sama lainnya, sedemikian rupa sehingga bagian-bagian tersebut merupakan suatu kesatuan pemrosesan atau pengolahan yang tertentu.

Dari definisi sistem diatas maka penyusun menyimpulkan bahwa sistem merupakan suatu jaringan kerja dari prosedurprosedur yang saling berhubungan, berkumpul bersama-sama untuk melakukan suatu kegiatan atau menyelesaikan suatu sasaran tertentu. Arti yang lain adalah kumpulan dari elemenelemen yang berinteraksi untuk mencapai tujuan tertentu.

\section{Pengertian Informasi}

Menurut [4] Informasi adalah data yang telah diolah menjadi bentuk yang lebih berarti dan berguna bagi penerimanya untuk mengambil keputusan masa kini maupun masa yang akan datang. Sedangkan menurut [6] Informasi merupakan salah satu sumber daya penting dalam manajemen modern.

Pendapat lain menurut [10] Informasi adalah data yang telah diproses sedemikian rupa sehingga meningkatkan pengetahuan seseorang yang menggunakan data tersebut. Seangkan pendapat lain menurut [11] Informasi adalah data yang telah diklasifikasi atau diolah atau diinterpretasi untuk digunakan dalam proses pengambilan keputusan.

Menurut [3] informasi adalah data yang telah diolah menjadi suatu bentuk yang penting bagi si penerimadan mempunyai nilai yang nyata yang dapat dirasakan dalam keputusan-keputusan yang sekarang atau keputusan-keputusan yang akan dating.

Secara umum informasi dapat didefinisikan sebagai hasil dari pengumpulan data dalam suatu bentuk yang lebih berguna dan lebih berarti bagi penerimanya yang menggambarkan suatu kejadian-kejadian yang nyata yang digunakan untuk pengambilan keputusan. Data yang diolah melaui suatu model menjadi informasi, penerima kemudian menerima informasi tersebut, membuat suatu keputusan dan melakukan tindakan, yang berarti menghasilkan suatu tindakan yang lain yang akan membuat sejumlah data kembali [3].

Dari definisi informasi diatas maka penyusun mengambil kesimpulan sebagai berikut, Informasi adalah data yang diolah menjadi sebuah bentuk yang lebih berguna bagi penerima dan dapat bermanfaat untuk mengambil keputusan. Sumber dari informasi adalah data. Data adalah kenyataan yang menggambarkan kejadian-kejadian dan kesatuan nyata.Informasi diperoleh setelah data-data mentah diproses atau diolah.

\section{Sistem Informasi}

Menurut [2] Sistem informasi merupakan suatu kumpulan dari komponen-komponen dalam suatu perusahaan atau organisasi yang berhubungan dengan prses penciptaan dan pengaliran infomasi. Dalam hal ini, TI hanya merupakan salah satu komponen dalam perusahaan. Komponen-komponen lainnya 
adalah prosedur, struktur organisasi, sumber daya manusia, produk, pelanggan, rekanan dan sebagainya. Keandalan suatu sistem informasi dalam organisasi terletak pada keterkaitan antar komponen yang ada, sehingga dapat dihasilkan dan dialirkan suat informasi yang berguna (akurat, terpercaya, detail, cepat, relevan, dan sebagainya) untuk lemabaga yang bersangkutan.

Sedangkan menurut [3], sistem informasi merupakan sistem yang mempuyai kemampuan untuk mengumpulkan informasi dari semua sumber dan menggunakan berbagai media untuk menampilkan informasi.

\section{PHP}

Menurut [12] PHP atau kependekan Hypertext Preprocessor adalah salah satu bahasa pemrograman open source yang sangat cocok atau dikhususkan untuk pengembangan web dan dapat ditanamkan pada sebuah skrip HTML [12]. Sistem kerja PHP diawali dengan permintaan yang berasal dari halaman website oleh browser. Berdasarkan URL atau alamat website dalam jaringan internet, browser akan menemukan sebuah alamat dari webserver, mengidentifikasi halaman yang dikehendaki, dan menyampaikan segala informasi yang dibutuhkan oleh webserver.

\section{MySQL (My Structure Query Language)}

Menurut [13], My Structure Query Language atau MySQL adalah salah satu Database Management System (DBMS) dari sekian banyak DBMS seperti Oracle, MS SQL, Postagre SQL, dan lainnya. MySQL berfungsi untuk mengolah database menggunakan bahasa SQL. MySQL bersifat open source sehingga dapat digunakan secara gratis.

[13], MySQL merupakan salah satu database kelas dunia yang sangat cocok bila dipadukan dengan bahasa pemrograman PHP. MySQL bekerja dengan menggunakan bahasa SQL (Structure Query Language) yang merupakan bahasa standar yang digunakan untuk manipulasi database

\section{Customer Relationship Management (CRM)}

[13], Manajemen Hubungan Pelanggan (Customer Relationship Management disingkat (RM) adalah suatu jenis manajemen yang secara khusus membahas teori mengenai penanganan hubungan antara perusahaan dengan pelanggannya, dengan tujuan meningkatkan nilai perusahaan di mata pelanggannya. Definisi CRM dipaparkan sebagai strategi manajemen relasi yang melibatkan pelanggan dengan penguna teknologi yang tepat.

Beberapa pengertian CRM dalam jurnal [14] adalah sebagai berikut:

1. CRM atau manajemen relasi pelanggan merupakan suatu proses mengelola informasi rinci tentang masing-masing pelanggan secara cermat, mengelola semua titik sentuhan pelanggan demi memaksimalkan kesetiaan pelanggan.

2. CRM adalah aktivitas, usaha dan strategi yang melibatkan seluruh sumber daya untuk menjalin, mengelola, dan mempertahankan hubungan dengan pelanggan yang ada, untuk mengetahui kebutuhan dan keinginan pelanggan.

3. CRM secara luas merupakan sebuah strategi bisnis dengan menggunakan teknologi informasi menyediakan suatu usaha yang menyeluruh, handal, dan berorientasi pada pelanggan yang terintegrasi, proses dan interaksi untuk mempertahankan serta memperluas manfaat hubungan kedua belah pihak.

Menurut [15] kunci proses-proses didalam CRM adalah sebagai berikut:

1. Pemasaran (marketing)

Proses pemasaran melibatkan keputusan yang menunjuk kepada pelangga dan target, bagiamana memberikan target kepada konsumen, produk apa yang ditawarkan, bagaimana harga produknya, dan bagaimana untuk memanajemen kampanye secara langsung yang menargetkan kepada pelanggan.

\section{Penjualan}

Proses penjualan berfokus pada penjualan langsung kepada seorang konsumen, dibandingkan dengan pemasaran di mana proses tersebut lebih berfokus kepada menyediakan tenaga penjualan dengan informasi yang mereka butuhkan dalam melaksanakan penjualan dan melakukan penjualan secara langsung.

\section{Manajemen Pemesanan}

Proses mengatur pesanan pelanggan yang berjalan dalam sebuah perusahaan sangatlah penting bagi konsumen dan perusahaan. Bagi konsumen, agar mereka dapat melacak pesanannya. Sedangkan untuk perusahaan adalah untuk merencanakan dan memenuhi pesanan tersebut.

\section{Call/Service Center}

Sebuah Service Center atau Call Center (pusat pengaduan) biasanya sebagai point utama dari kontak atara perusahaan dengan pelanggan. Sebuah Service Center membantu pelanggan untuk pemesanan, penyaranan produk, memecahkan masalah, dan menyediakan informasi terhadap status pesanan.

Sasaran utama CRM adalah meningkatkan pertumbuhan jangka panjang dan profitabilitas perusahaan melalui pengertian yang lebih baik terhadap kebiasaan (behavior) pelanggan. Sedangakan, tujuan dari CRM itu sendiri adalah untuk menyiapkan umpan balik yang lebih efektif dan integrasi yang lebih baik dengan pengendalian return on investment (ROI) di area ini.

Fungsi dari CRM itu sendiri adalah sebagai berikut:

1. Mengidentifikasi faktor-faktor yang penting bagi pelanggan.

2. Mengusung falsafah customer-oriented (customer centric).

3. Mengadopsi pengukuran berdasarkan sudut pandang pelanggan.

4. Membangun proses ujung ke ujung dalam melayani pelanggan.

5. Menyediakan dukungan pelanggan yang sempurna.

6. Menangani keluhan/komplain pelanggan.

7. Mencatat dan mengikuti semua aspek dalam penjualan.

8. Membuat informasi holistik tentang informasi layanan dan penjualan dari pelanggan.

Manfaat menggunakan sistem CRM dalam jurnal [14] adalah:

1. Improve customer satisfaction/Meningkatkan kepuasan pelanggan.

2. Share customer information more easly/Berbagi informasi.

3. Increase sales by up sellig and cross selling other products. 
4. Identify most profitabel and unprofitabel customer/mengidentifikasi pelanggan yang paling menguntungkan dan pelanggan yang tidak menguntungkan.

\section{METODOLOGI}

Metode pendekatan sistem yang digunakan oleh penulis adalah pendekatan berbasis objek. Terdapat beberapa alasan penulis menggunakan pendekatan berbasis objek diantaranya adalah mudah dipahami dan mudah digunakan artinya metode ini mudah dimengerti. Metode Extreme Programming merupakan suatu pendekatan yang paling banyak digunakan untuk pengembangan perangkat lunak. Alasan menggunakan metode Extreme Programming karena sifat dari aplikasi yang di kembangkan dengan cepat melalui tahapan-tahapan yang ada meliputi: Planning / Perencanaan, Design / Perancangan, Coding / Pengkodean dan Testing /Pengujian.

1. Tahap awal, yaitu adalah tahap perencanaan (Planning) ), adalah menyangkut studi studi tentang kebutuhan pengguna (user's specification), studi-studi kelayakan (feasibility study) baik secara teknik maupun secara teknologi serta penjadwalan suatu proyek sistem informasi atau perangkat lunak. pada tahap ini pula, sesuai dengan kakas (tool) yang penulis gunakan yaitu UML.

2. Tahap kedua, adalah tahap perencanaan (Design)

3. Tahap ketiga, adalah tahap implementasi (pengkodean / Coding).

4. Tahap keempat, adalah pengujian (Testing), yang dapat digunakan untuk menentukan apakah sistem atau perangkat lunak yang dibuat sudah sesuai dengan kebutuhan pengguna atau belum, jika belum, proses selanjutnya adalah bersifat iteratif, yaitu kembali ketahap-tahap sebelumnya.

Setelah implementasi sistem selesai, maka selanjutnya dilakukan pengujian sistem. Pendekatan pengujian yang digunakan pada penelitian ini adalah pengujian black-box. Pengujian black-box berkaitan dengan pengujian yang dilakukan pada interface perangkat lunak. Pengujian black-box digunakan untuk memperlihatkan bahwa fungsi-fungsi perangkat lunak adalah operasional; bahwa input diterima dengan baik dan output dihasilkan dengan tepat, dan integritas informasi eksternal (seperti file data) dipelihara. Pengujian black-box berusaha menemukan kesalahan dalam kategori sebagai berikut: 1). Fungsi-fungsi yang tidak benar atau hilang; 2). Kesalahan interface; 3). Kesalahan dalam struktur data atau akses database eksternal; dan 4). Kesalahan kinerja.

\section{Analisa Sistem Yang Sedang Berjalan}

Dari pengamatan yang dilakukan penulis pada PT Sumber Alfaria Trijaya Tbk (Indomaret) Batam bagian CRM (Customer Relationship Management), maka aliran sistem informasi yang sedang berjalan pada PT Sumber Alfaria Trijaya Tbk (Indomaret) Batam adalah sebagai berikut:

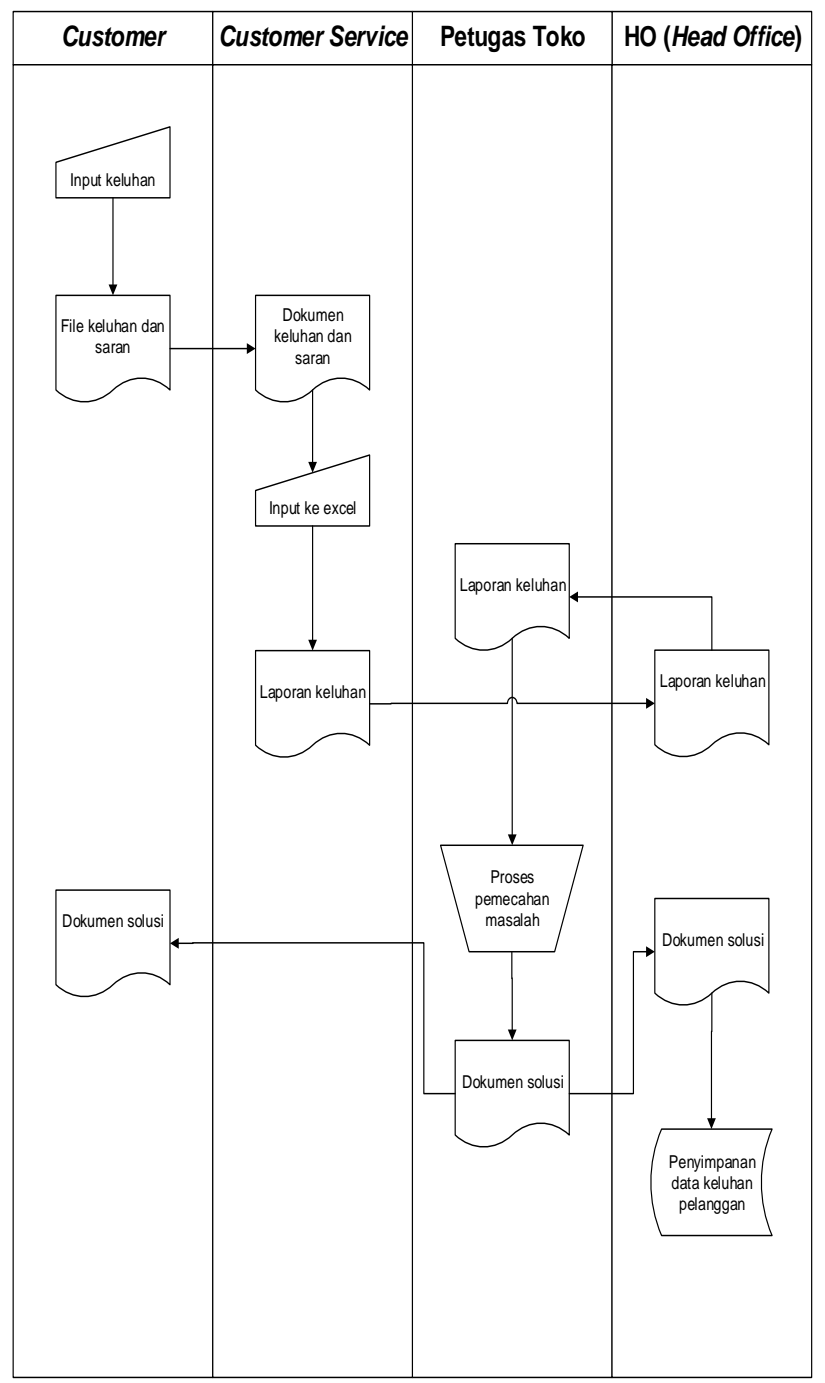

Gambar 1. Aliran Sistem Informasi Yang Sedang Berjalan

\section{Permasalahan Yang Sedang Dihadapi}

Berdasarkan analisis pada sistem informasi yang sedang berjalan pada proses pengelolaan Customer Relationship Management (CRM) pada PT Sumber Alfaria Trijaya Tbk (Indomaret) Batam, dapat diketahui beberapa kelemahan yaitu sebagai berikut:

1. Pada proses pengelolaan CustomerRelationship Management (CRM) yang berhubungan langsung dengan komplain pelanggan masih menggunakan media telphone, $e$ mail, dan sms, serta sosial media seperti facebook dan twitter.

2. Pada sistem yang berjalan, customer sering menyampaikan komplai ke toko yang di mana karyawan Indomaret Batam hanya bisa mendengarkan dan memberikan solusi dengan apa yang mereka ketahui, akan tetapi komplain tersebut jarang sampai ke Customer Service perusahaan sehingga perusahaan tidak mengetahui apa yang diingin kan pelanggan.

3. Sering terjadinya komplain melalui media sosial (bukan pada media yang disediakan oleh perusahaan) oleh pelanggan yang akan mencemarkan nama baik perusahaan dan mengurangi kepercayaan pelanggan sehingga pelanggan tidak loyal lagi terhadap perusahaan. 


\section{Usulan Pemecahan Masalah}

Dari permasalahan diatas, maka penulis mengusulkan beberapa saran untuk menyelesaikan permasalahan di atas:

1. Mengusulkan sistem pengelolaan Customer Relationship Management (CRM) berbasis web untuk mempermudah customer menyampaikan komplain serta saran apa yang pelanggan inginkan yang lebih bersifat tertutup.

Membuat rancangan program untuk melengkapi sistem yang sudah ada dengan sistem informasi berbasis website..

\section{HASIL DAN PEMBAHASAN}

\section{Aliran Sistem Informasi yang Baru}

Implementasi sistem yang diterapkan pada obyek yang diteliti membutuhkan penelitian dan analisa terhadap efektifitas dan efisiensi kerjanya, sehingga baik yang merencanakan (sistem analis), yang memprogram (programmer), dan juga yang memanfaatkan atau mengutilisasi sistem tersebut menjadi mengerti apa saja kelebihan dan kekurangan sistem secara mendetil, kendala yang dihadapi dalam pengoperasiannya, serta bagaimana cara mencegah kemungkinan-kemungkinan yang dapat mengancam kelangsungan operasional sistem dan memperbaiki kerusakan sistem yang terlanjur terjadi.

Untuk dapat memahami mekanisme dari sistem yang sedang berjalan, maka perlu ditelaah desain-desain dan rancangan awal dari suatu sistem sampai tahap-tahap terbentuknya sistem tersebut melalui fabrikasi program. Secara umum, analisa dilakukan pada segmen yang membentuk program sistem informasi tersebut, antara lain desain global, dan desain rinci. Desain global meliputi tahap-tahap perancangan di atas kertas atau logika pembentuk program. Desain rinci adalah tahap perancangan yang lebih memfokuskan pada layout atau bentuk kasarnya program yang akan dibuat.

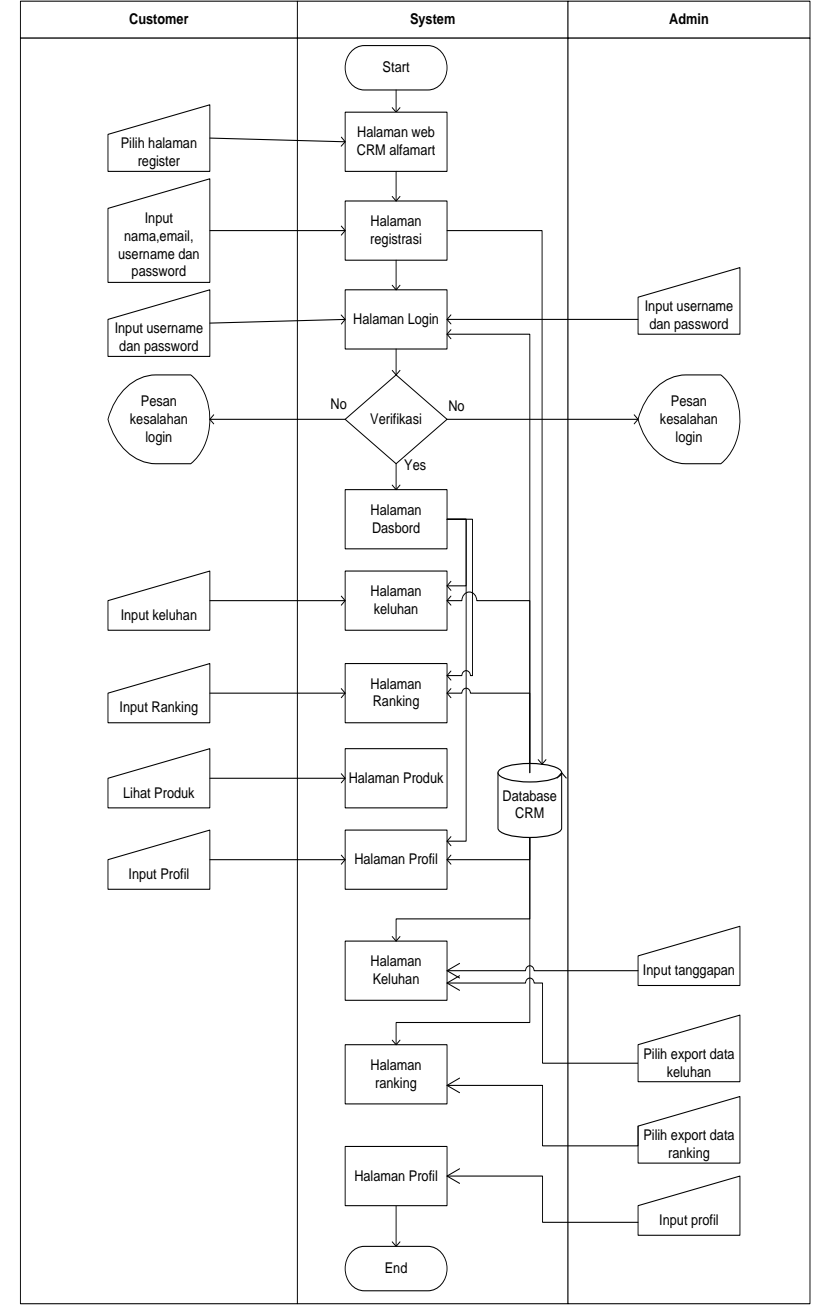

Gambar 2. Aliran Sistem Informasi Yang Baru

\section{Use case Diagram}

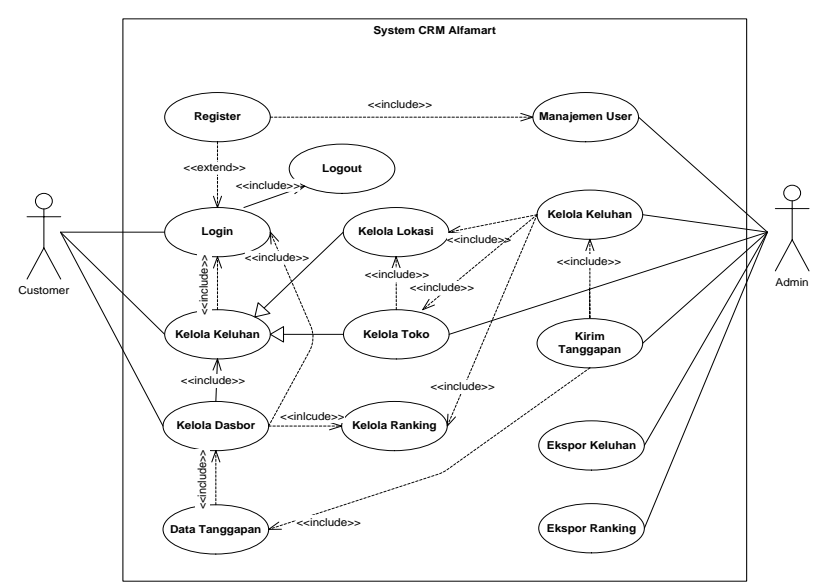

Gambar 3. UsecaseDiagram Sistem Informasi CRM

\section{Activity Diagram}

Activity DiagramLogin

Admin yang memiliki akses penuh dan bertanggung jawab atas berjalanya sebuah sistem, maka admin berhak memberi dan mengganti password atas setiap akses yang akan di gunakan oleh setiap user dalam proses kerja pada sistem. 


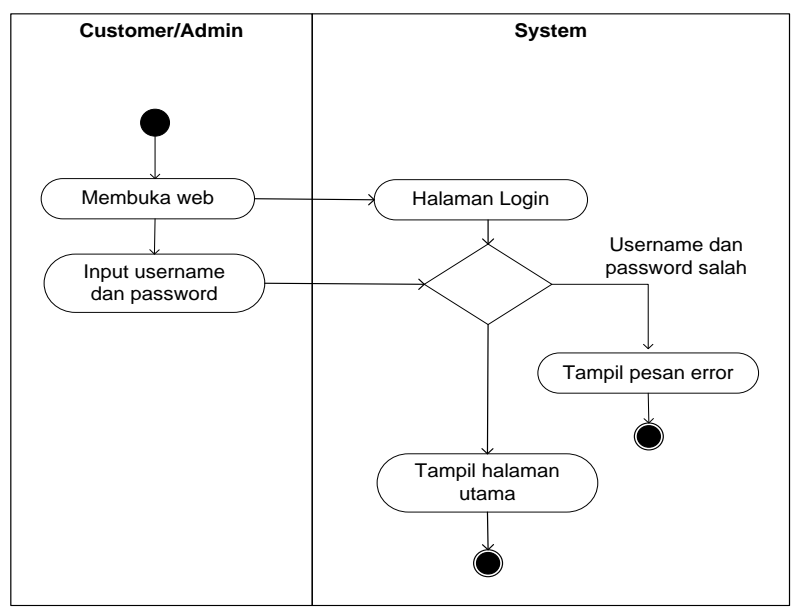

Gambar 4. Activity Diagram Login

Activity Diagram Register

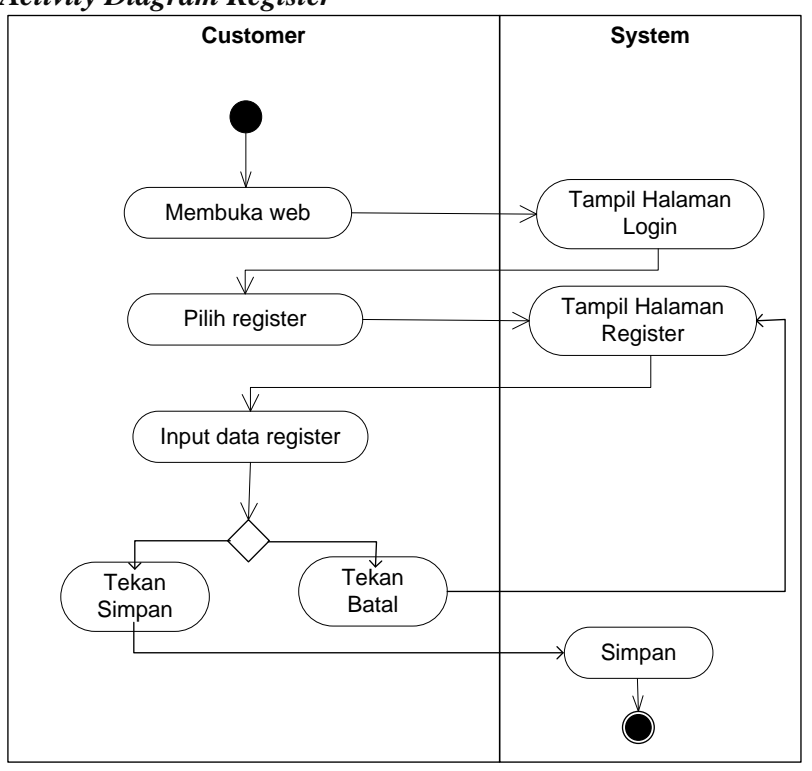

Gambar 5. Activity Diagram Register

\section{Actifity Diagram Lihat Keluhan}

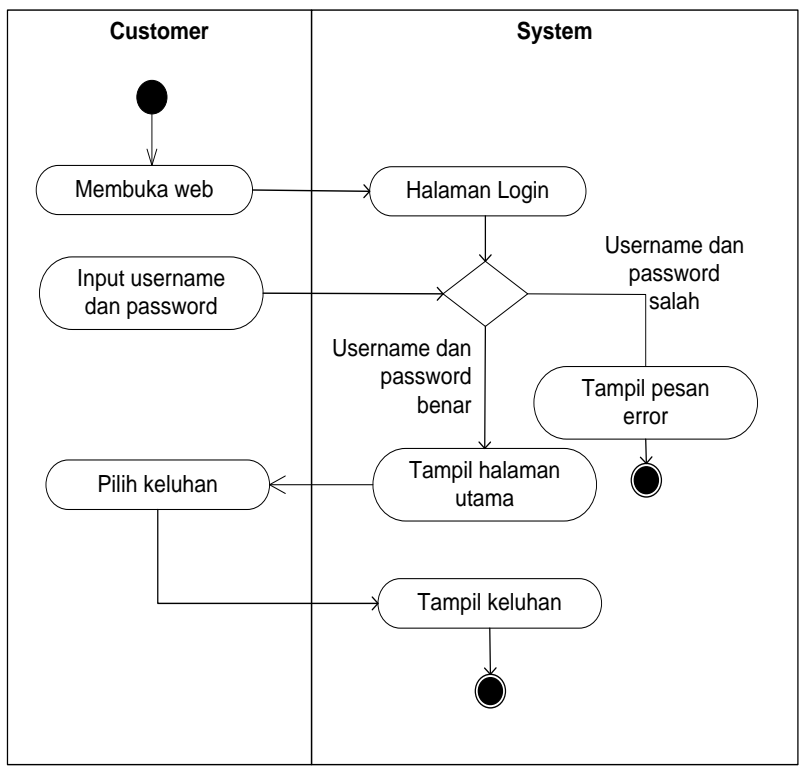

Gambar 6. Actifity Diagram Lihat Keluhan

\section{Actifity Diagram Tambah Keluhan}

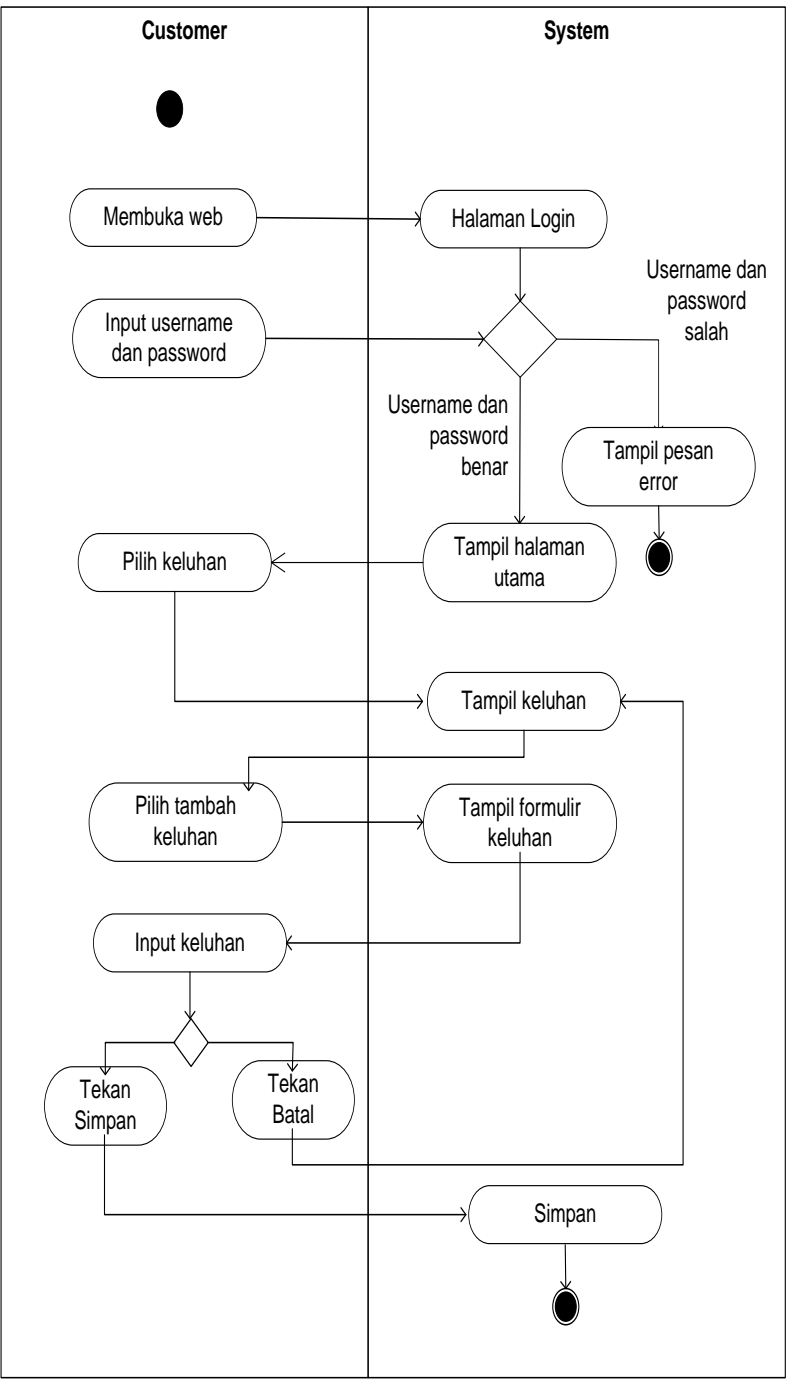

Gambar 7. Actifity Diagram Tambah Keluhan 
Actifity Diagram Input Rangking

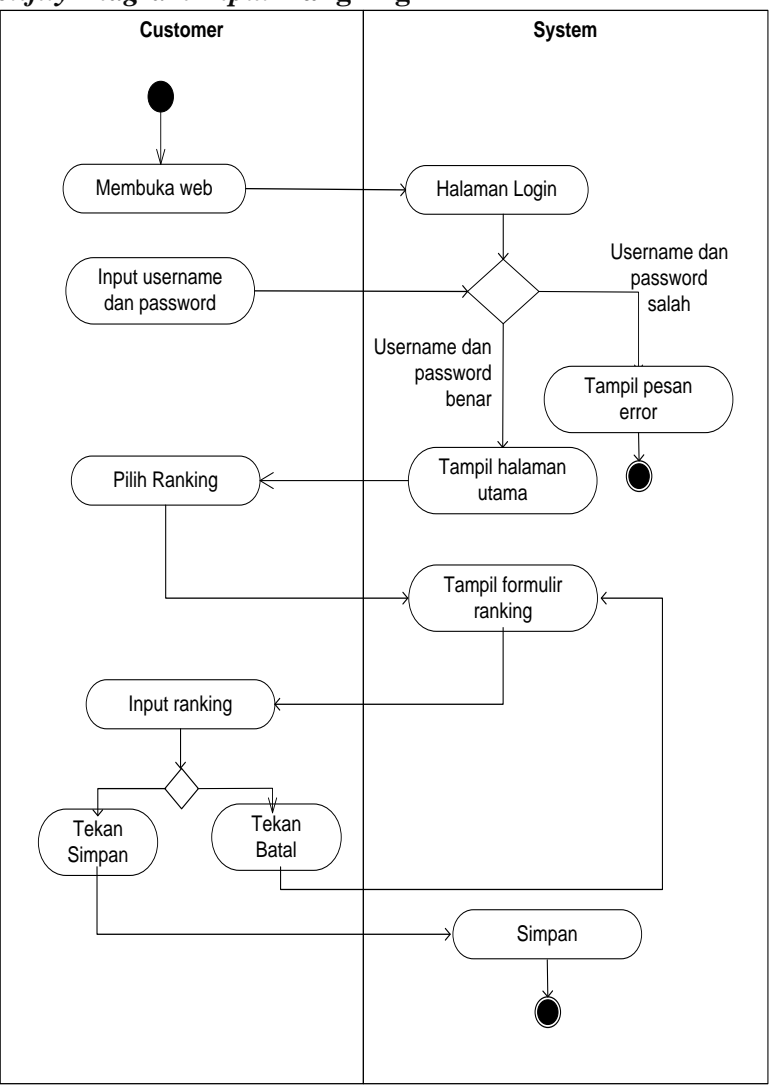

Gambar 8. Activity DiagramInput Rangking

\section{Actifity Diagram Input Profile}

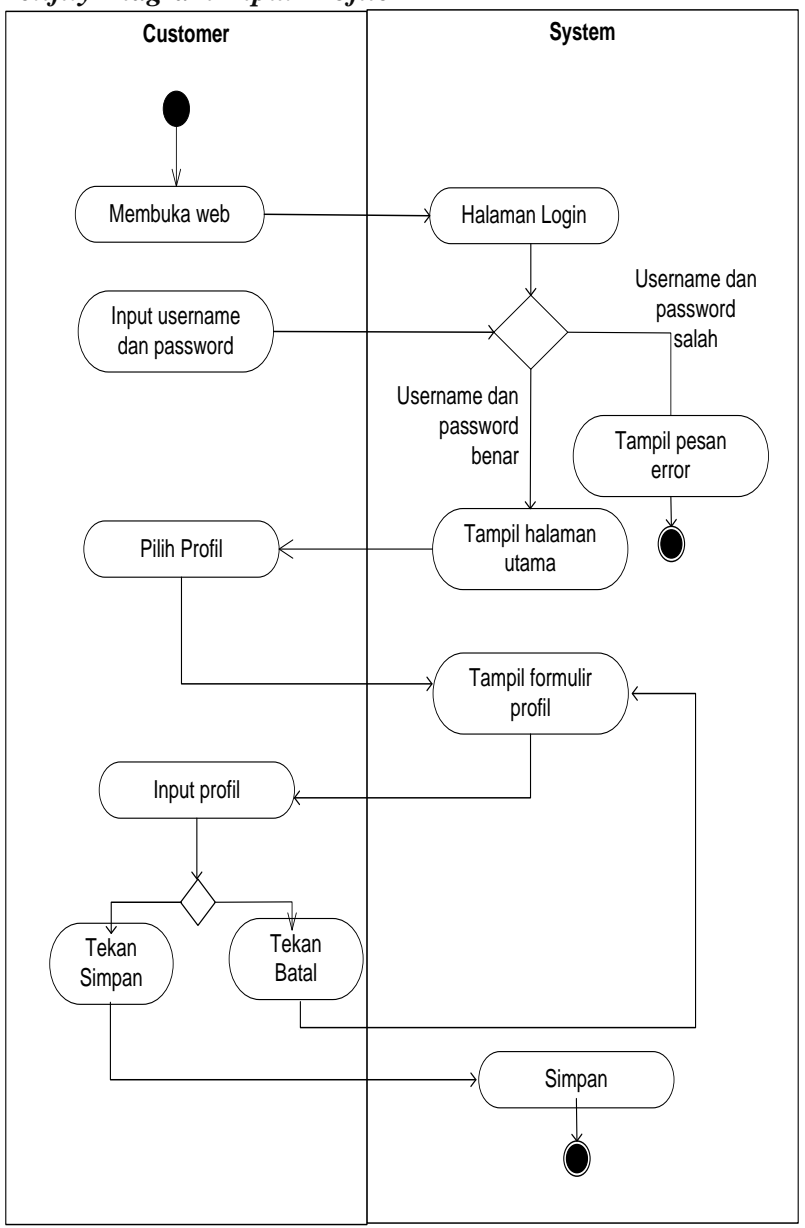

Gambar 9. Activity Diagram Input Profile
Actifity Diagram Admin Lihat Keluhan

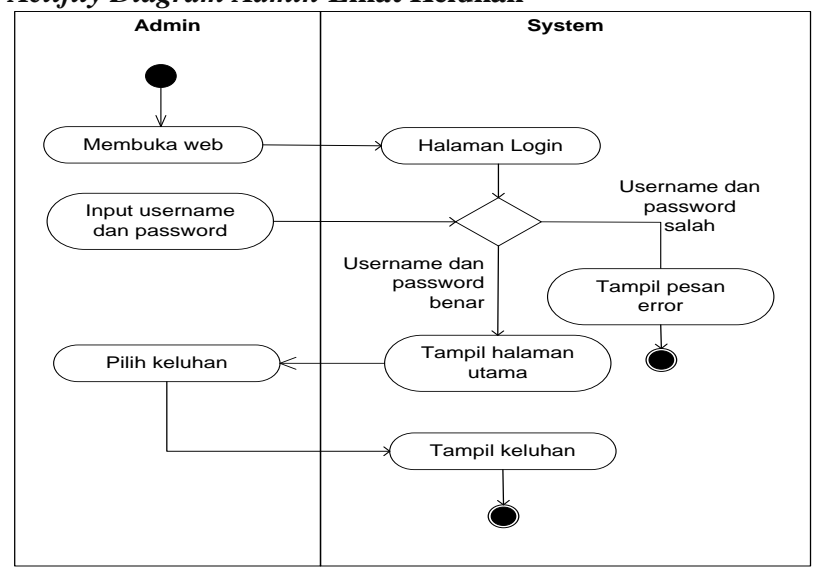

Gambar 10. Actifity Diagram Admin Lihat Keluhan

Actifity DiagramAdmin Proses Keluhan

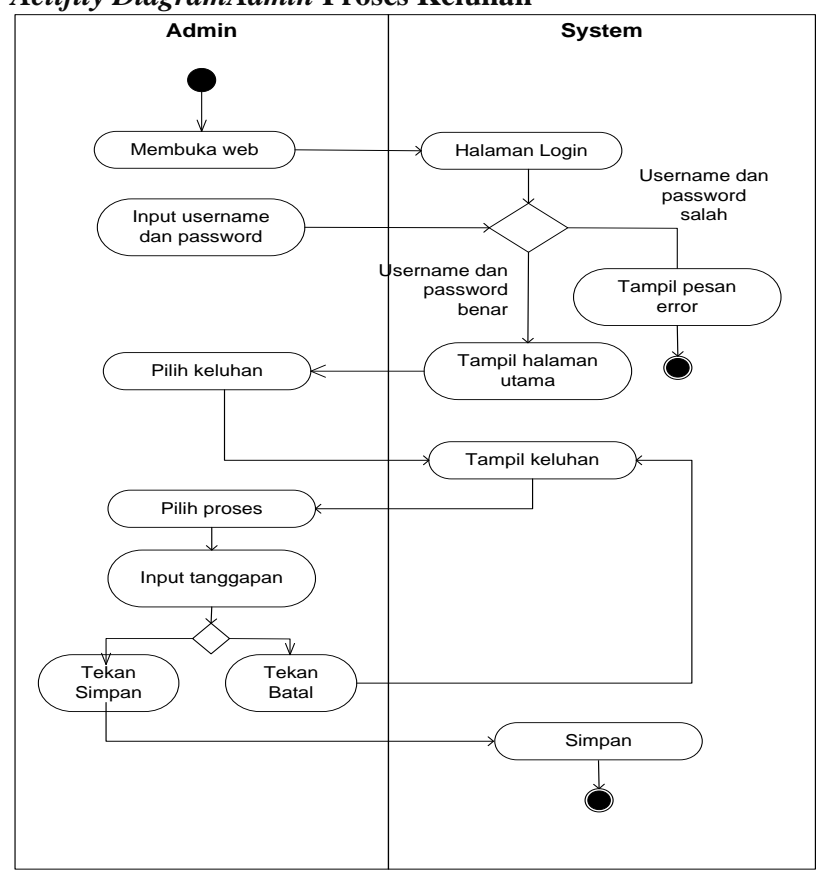

Gambar 11. Actifity Diagram Admin Proses Keluhan

Actifity Diagram Admin Export Keluhan

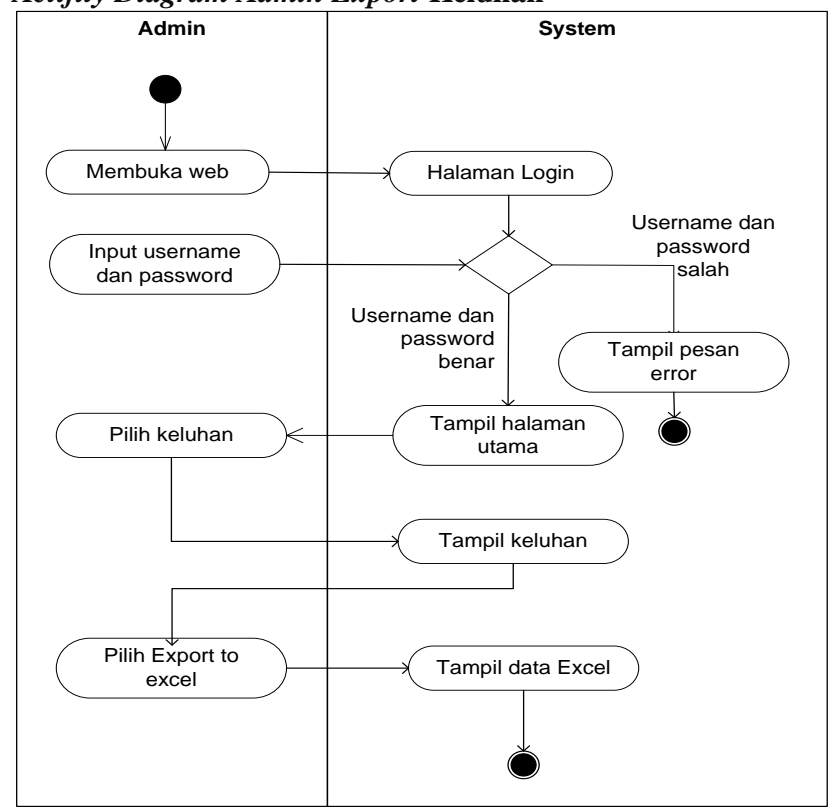

Gambar 12. Actifity Diagaram Adm Export Keluhan

Tukino 
Actifity Diagram Admin Tampilkan Rangking

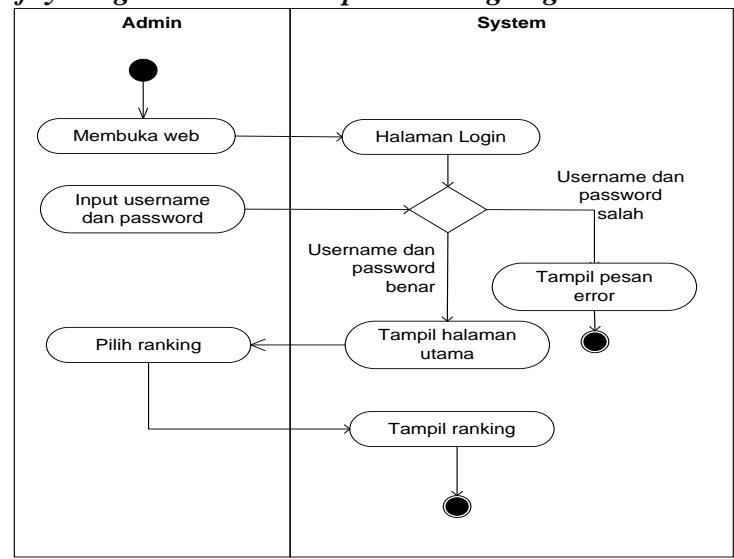

Gambar 13. Acifity Diagram Adm Tampilkan Rangking

\section{Sequence Diagram}

Sequence diagram menggambarkan tahap demi tahap aliran proses yang terjadi dalam suatu use case. Sequence menjelaskan interaksi objek yang disusun dalam urutan kejadian yang dilakukan aktor dalam menjalankan sistem. Berikut diagramnya:

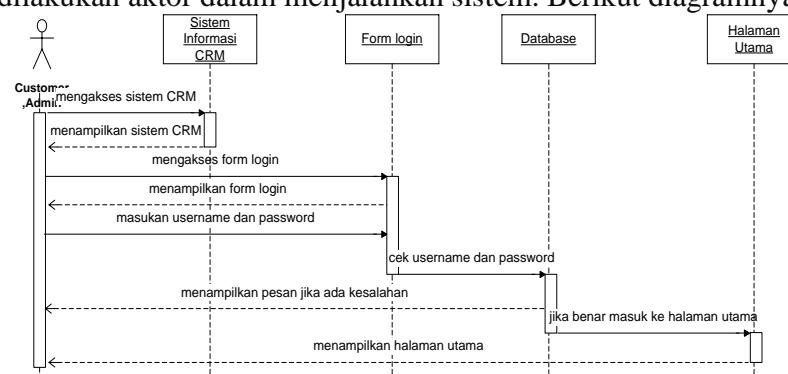

Gambar 14. Sequence Diagram Form Login

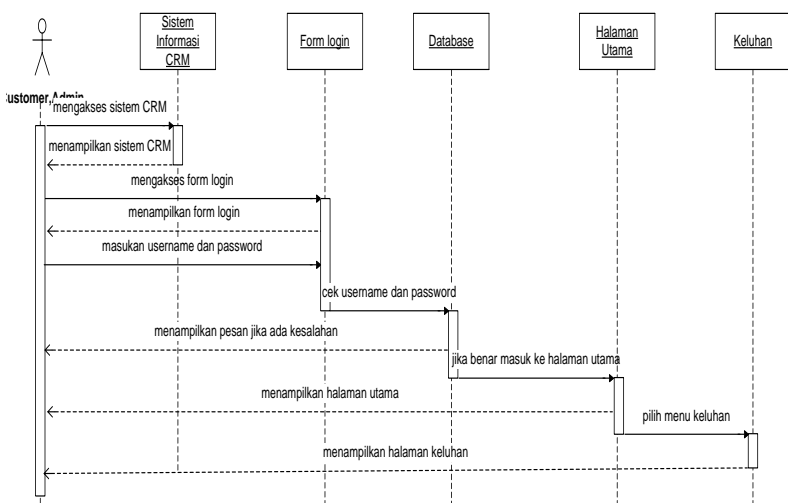

Gambar 15. Sequence Diagram View Keluhan

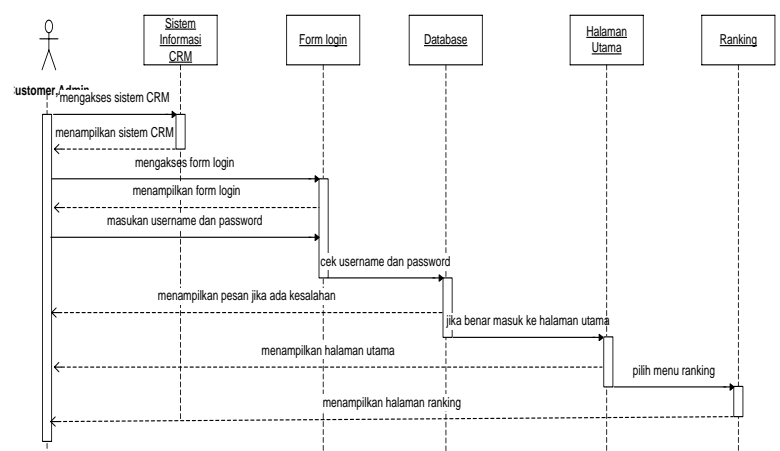

Gambar 16. Sequence Diagram View Rangking

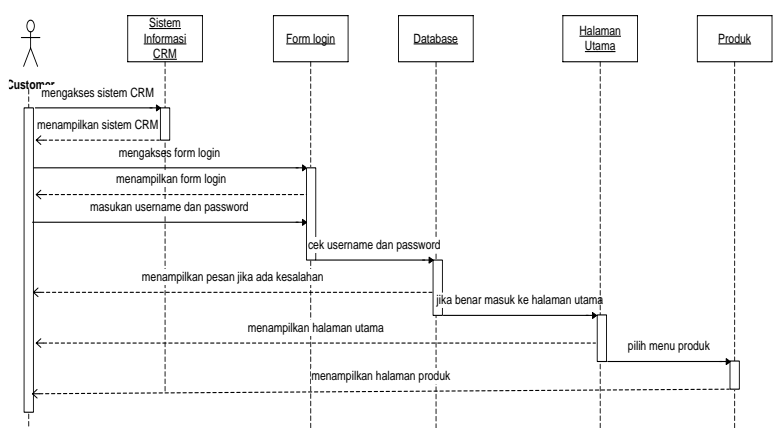

Gambar 17. Sequence Diagram View Produk

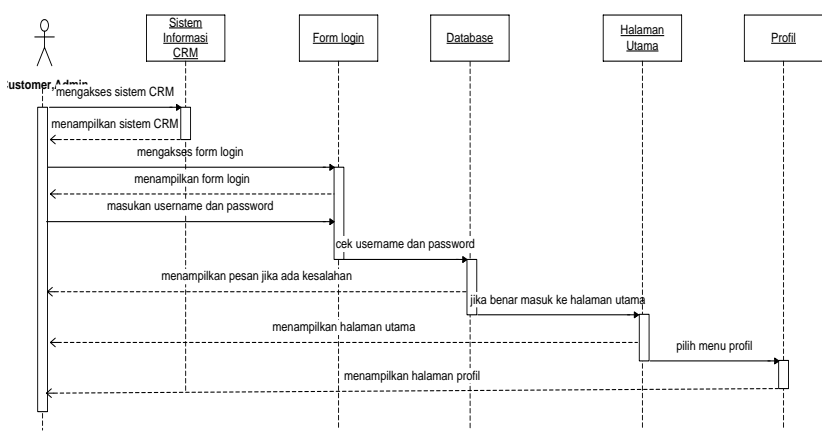

Gambar 18. Sequence Diagram View Profile

\section{Class Diagram}

Class diagram membantu menampilkan visuaisasi struktur class-class dalam suatu sistem dan merupakan tipe diagram yang paling banyak dipakai. Diagram memberikan gambaran detail mengenai class dalam model desain dari suatu sistem. Berikut class diagram dari sistem yang diajukan:

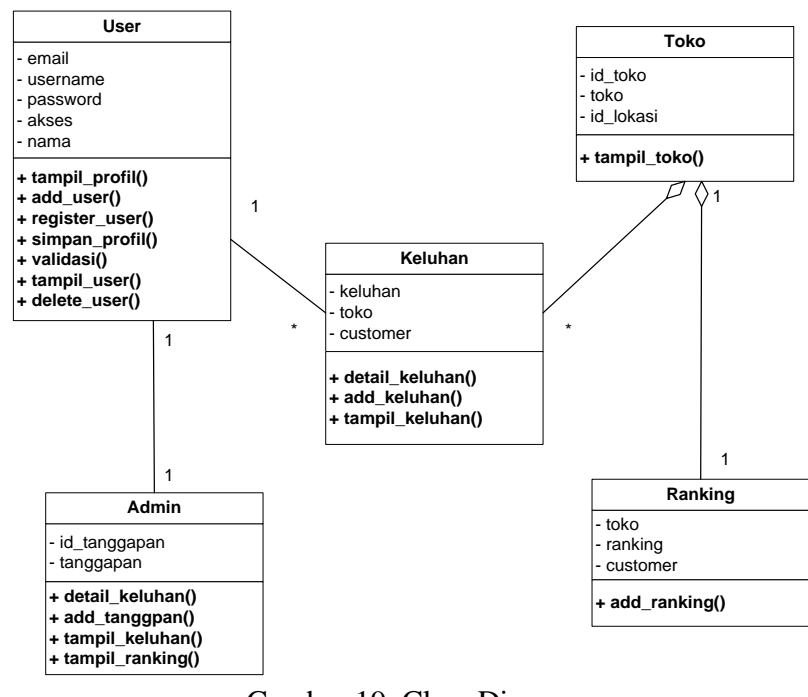

Gambar 19. Class Diagram

Tampilan Program

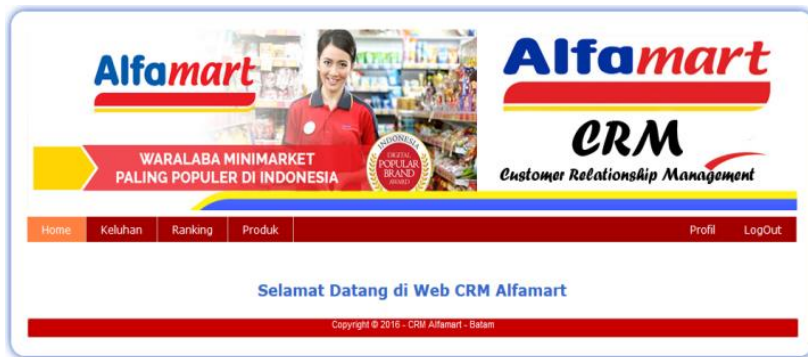

Gambar 20. Halaman Welcome

DOI: https://doi.org/10.30743/infotekjar.v3i2.848 


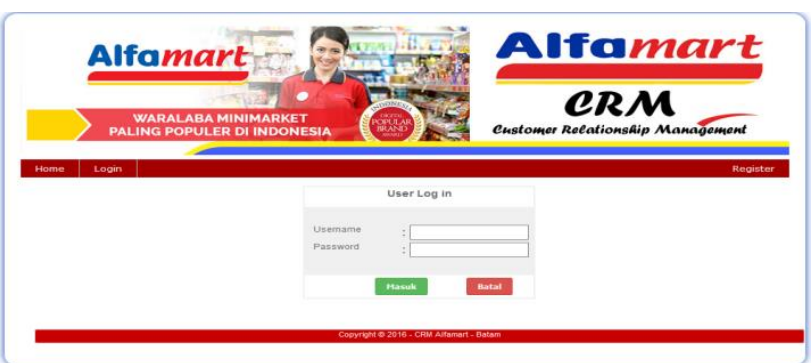

Gambar 21. Halaman Login Admin

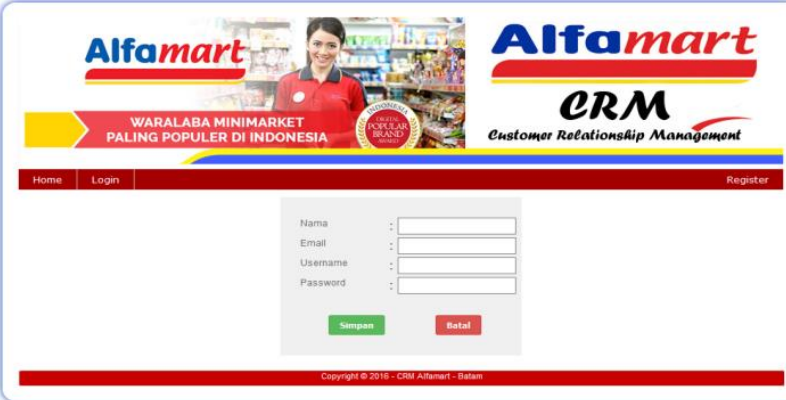

Gambar 22. Halaman Register

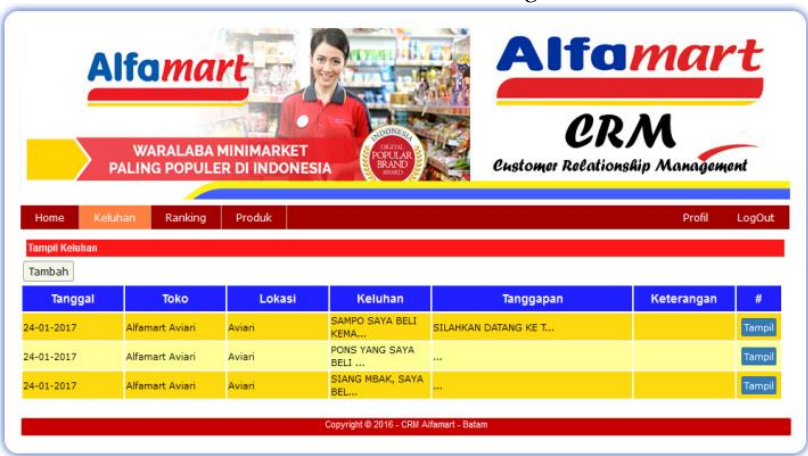

Gambar 23. Halaman Keluhan Pelanggan
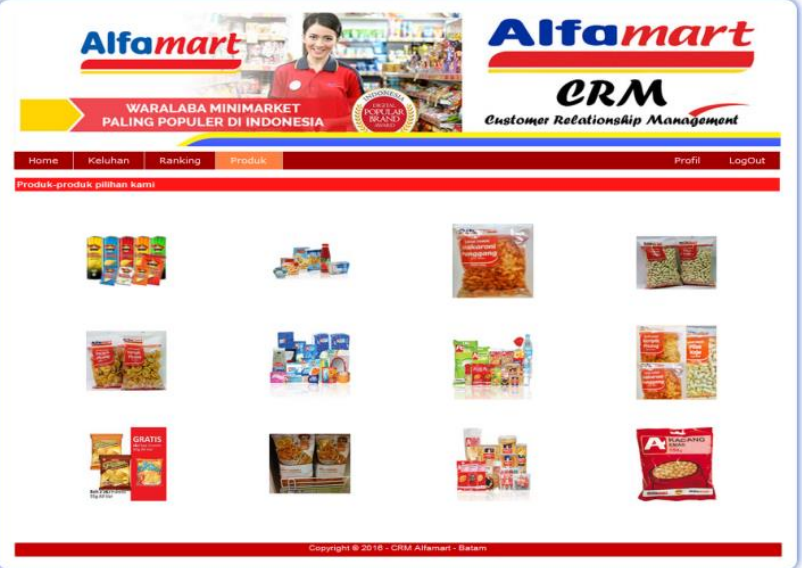

Gambar 24. Halaman Produk

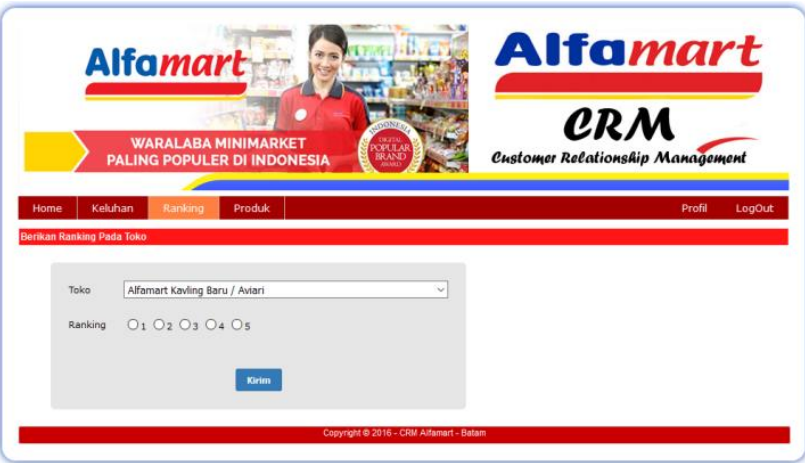

Gambar 25. Halaman Rangking

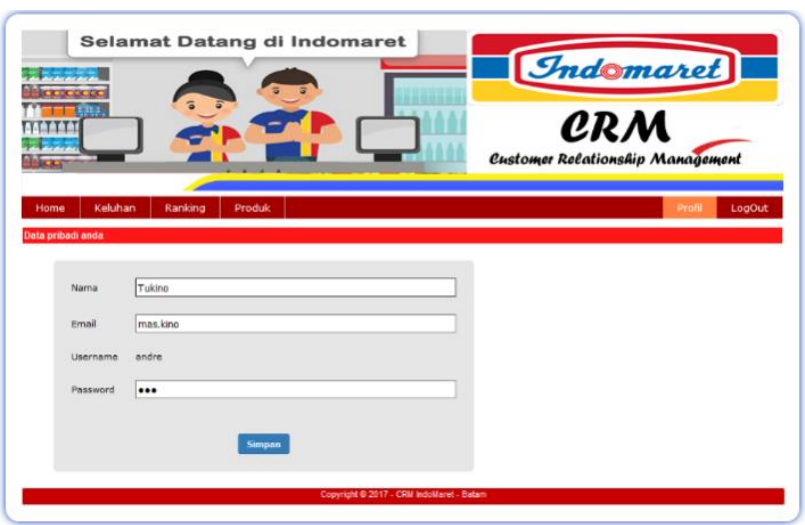

Gambar 26. Halaman Profile

Tabel 1. Fungsi Menu

\begin{tabular}{|c|c|c|}
\hline No. & Nama Halaman & Fungsi \\
\hline 1 & Halaman Register & $\begin{array}{ll}\text { Menampilkan } & \text { halaman } \\
\text { register untuk mendaftar } \\
\text { sebagai user dan masuk ke } \\
\text { halaman login }\end{array}$ \\
\hline 2 & Halaman Login & $\begin{array}{l}\text { Menampilkan halaman login } \\
\text { untuk masuk ke aplikasi }\end{array}$ \\
\hline 3 & Halaman Utama & $\begin{array}{l}\text { Menampilkan } \\
\text { halaman utama atau main } \\
\text { menu }\end{array}$ \\
\hline 4 & Halaman Keluhan & $\begin{array}{l}\text { Menampilkan daftar keluhan } \\
\text { dan tools tambah untuk input } \\
\text { keluhan }\end{array}$ \\
\hline 5 & Input Keluhan & $\begin{array}{l}\text { Menampilkan halamn input } \\
\text { keluhan untuk memberikan } \\
\text { keluhan yang dikeluhkan oleh } \\
\text { customer }\end{array}$ \\
\hline 6 & Halaman Rangking & $\begin{array}{l}\text { Menampilkan halaman } \\
\text { rangking untuk memberikan } \\
\text { rangking atau nilai kepada } \\
\text { toko yang diinginkan }\end{array}$ \\
\hline 7 & Produk & $\begin{array}{l}\text { Menampilkan daftar produk } \\
\text { dalam bentuk iklan promo }\end{array}$ \\
\hline 8 & Profile & $\begin{array}{l}\text { Menampilkan halaman profile } \\
\text { dari user yang sedang login } \\
\text { atau aktif. Halaman ini juga } \\
\text { berfungsi untuk mengganti } \\
\text { profileuser }\end{array}$ \\
\hline 9 & Home Admin & $\begin{array}{l}\text { Manampilkan Halaman utama } \\
\text { Admin }\end{array}$ \\
\hline 10 & Admin_keluhan & $\begin{array}{l}\text { Menampilkan daftar keluhan } \\
\text { customer untuk diproses dan } \\
\text { tools proses buat menaggapi } \\
\text { keluhan serta tools export } \\
\text { untuk membuat laporan } \\
\text { keluhan customer }\end{array}$ \\
\hline 11 & Admin_tanggapan & $\begin{array}{l}\text { Menampilkan halaman } \\
\text { tanggapan yang berisikan } \\
\text { keluhan serta input tanggapan } \\
\text { yang akan diberikan kepada } \\
\text { customer }\end{array}$ \\
\hline 12 & Admin Rangking & $\begin{array}{lr}\text { Menampilkan } & \text { halaman } \\
\text { rangking } & \text { yang } \\
\text { diinputcustomer, dan botton } \\
\text { export untuk } & \text { membuat } \\
\text { laporan } & \\
\end{array}$ \\
\hline 13 & User & $\begin{array}{l}\text { Menampilkan halaman yang } \\
\text { berisi daftar user yang yang } \\
\text { diberi izin } \quad \text { untuk } \\
\text { menggunakan aplikasi }\end{array}$ \\
\hline
\end{tabular}




\begin{tabular}{|c|l|l|}
\hline No. & \multicolumn{1}{|c|}{ Nama Halaman } & \multicolumn{1}{|c|}{ Fungsi } \\
\hline 14 & Adduser & $\begin{array}{l}\text { Menampilkan halaman yang } \\
\text { untuk menambah user baru } \\
\text { kedalam database }\end{array}$ \\
\hline 15 & Deleteuser & $\begin{array}{l}\text { Menempilkan opsi pilihan } \\
\text { untuk menghapus user atau } \\
\text { tidak }\end{array}$ \\
\hline
\end{tabular}

\section{Perbandingan Sistem}

Perbandingan sistem lama dan sistem baru pada PT Sumber Alfaria Trijaya Tbk (Indomaret) Batam, dapat dilihat dalam tabel berikut:

Tabel 2. Perbandingan Sistem Lama dan Sistem Baru

\begin{tabular}{|c|c|}
\hline Sistem Lama & Sistem Baru \\
\hline $\begin{array}{l}\text { Keunggulan: } \\
\text { 1. Tidak membutuhkan } \\
\text { biaya yang cukup besar } \\
\text { untuk implementasi dan } \\
\text { perangkat } \\
\text { digunakan yang } \\
\text { perusahaan. }\end{array}$ & $\begin{array}{l}\text { Keunggulan: } \\
\text { 1. Laporan data keluhan } \\
\text { pelanggan akan } \\
\text { terdokumentasi dan } \\
\text { tersimpan dengan baik. } \\
\text { 2. Proses dan waktu } \\
\text { pengelolaan keluhan } \\
\text { pelanggan akan lebih } \\
\text { cepat. } \\
\text { 3. Keuntungan } \\
\text { pelanggan, hanya akan } \\
\text { dikenakan biaya internet } \\
\text { untuk membuka website } \\
\text { tersebut. } \\
\text { 4. Lebih bersifat pribadi } \\
\text { 5. Sarana promosi bagi } \\
\text { perusahaan. }\end{array}$ \\
\hline $\begin{array}{l}\text { Kelemahan: } \\
\text { 1. Bengkaknya biaya yang } \\
\text { dikeluaran pelanggan } \\
\text { dalam menyampaikan } \\
\text { keluhan melalui telphone. } \\
\text { 2. Membutuhkan waktu dan } \\
\text { proses yang lama dalam } \\
\text { memberikan tanggapan } \\
\text { atau permohonan maaf } \\
\text { kepada pelanggan yang } \\
\text { menyampaikan keluhan. } \\
\text { 3. Hilangnya data keluhan } \\
\text { pelanggan karena data } \\
\text { keluhan tidak } \\
\text { terdokumentasi dengan } \\
\text { baik. }\end{array}$ & $\begin{array}{l}\text { Kelemahan: } \\
\text { 1. Diperlukannya biaya yang } \\
\text { besar untuk pengelolaan } \\
\text { sistem. } \\
\text { 2. Pelanggan harus masuk } \\
\text { kesistem kalau ingin } \\
\text { melihat masukan atau } \\
\text { balasan dari keluhannya. }\end{array}$ \\
\hline
\end{tabular}

\section{Analisis Produktifitas}

Dengan menggunakan sistem yang baru diharapkan semua data yang berhubungan dengan gangguan dapat menghasilkan informasi yang tepat dan akurat sesuai dengan yang diharapkan oleh Pihak Manajemen dan pelanggan dalam mencapai tujuan dari PT Sumber Alfaria Trijaya Tbk (Indomaret) Batam. Sehingga semua kendala yang selama ini terjadi dapat teratasi.

\section{Segi Efisiensi}

Sistem CRM ini dirancang dengan sedemikian rupa dengan tujuan untuk mempermudah penguna sistem dalam proses manipulasi data CRM. Beberapa keunggulan yang dapat di lihat dari segi efisiensi pada sistem ini antara lain:

1. Sistem CRM ini membuat laporan dengan lebih cepat dan akurat.Biasanya, laporan yang dibuat harus mengumpulkan semua keluhan pelanggan yang disampaikan dengan berbagai media yang disediakan, sedangkan untuk sekarang, cukup dengan sistem ini maka laporan keluhan pelanggan dapat terdokumentasi dengan baik tanpa harus mengumpulkan berbagai keluhan yang disampaikan dari media lain.

2. Sistem ini membuat proses pengolahan dan penanganan keluhan menjadi lebih cepat.

3. Penanganan keluhan pelanggan biasanya membutuhkan waktu yang lama dalam penanganannya, karena dari customerservice keluhan akan diberikan ke Departemen CRM terus Area Manager lalu ditangani oleh Kordinator Wilayah yang akan menyampaikan permohonan maaf dan tanggapan atas apa yang dikeluhkan pelanggan. Sedangkan, dengan sistem ini Dept CRM cukup memberikan tanggapan melalui sistem ke pada pelanggan dan personil toko ataupun korwil akan menyelesaikan masalah tersebut di toko.

\section{Segi Efektifitas}

Beberapa keunggulan yang dapat di lihat dari segi efektifitas pada sistem ini antara lain:

1. Lebih hemat kertas.

Customerservice membutuhkan kertas untuk mencatat berbagai laporan keluhan pelanggan dari media yang disediakan untuk menyampaikan keluhan. Sedangkan, dengan sistem yang dirancang, Customer service ataupun pihak CRM tidak perlu banyak mengeluarkan kertas untuk mencatat laporan keluhan karena sistem akan mengelola daftar keluhan dan membuatnya dalam bentuk laporan excel, otomatis biaya operasianalnya lebih sedikit.

2. Mengunakan database untuk media penyimpanan data CRM yang lebih aman.

3. Mempermudah dalam memberikan nilai terhadap toko yang ada di cabang.

Memberikan nilai terhadap toko dilakukan oleh tim audit dengan mendatangi langsung toko yang akan diaudit. Oleh sebab itu, dengan adanya sistem ini perusahaan dapat melihat seperti apa kinerja toko dan pelayanan toko terhadap pelanggan melalui nilai atau rangking kepuasan yang diberikan oleh pelanggan.

\section{KESIMPULAN DAN SARAN}

\section{Simpulan}

Berdasarkan analisa dan pembahasan tersebut, maka penulis dapat mengambil kesimpulan sebagai berikut:

1. Customer Relationship Management (CRM) merupakan manajemen yang mengelola hubungan perusahaan dengan pelanggan yang akan meningkatkan nilai perusahaan di mata pelanggan dengan menggunakan teknologi yang tepat seperti Sistem Informasi Customer Relationship Management (CRM) berbasis web.

2. Perancangan sistem informasi Customer Relationship Management (CRM) pada PT Sumber Alfaria Trijaya Tbk (Indomaret) Batam dilakukan dengan pemodelan sistem menggunakan diagram UML (Unified Modelling Language), yang menghasilkan sebuah sistem untuk mempermudah pelanggan dalam menyampaikan pendapat dan mempermudah admin dalam mengelola laporan keluhan pelanggan.

3. Pengelolaan dan pengaturan dokumen keluhan pelanggan serta data pelanggan dapat dilakukan lebih efisien dengan sistem yang dibuat, sehingga dapat memberikan pelayanan yang diinginkan oleh pelanggan dan mencapai kepuasan pelanggan. 


\section{Saran}

Pada pengembangan sistem Customer Relationship Management (CRM) ini masih banyak terdapat kekurangan, sehingga dapat dikembangkan lagi dengan penambahanpenambahan yang belum terdapat dalam penulisan sebelumnya. Beberapa saran yang diberikan agar dapat dijadikan bahan pertimbangan, antara lain:

1. Sistem tetap ditingkatkan baik dalam performa maupun penambahan fitur-fitur lain dalam sistem. Jika diperlukan dilakukan peng-upgrade-an sistem supaya sistem tetap up to date.

2. Sistem Customer Relationship Management (CRM) dapat dikembangkan menjadi sebuah aplikasi khusus untuk perusahaan sepertisistem berbasis android sehingga dapat didownload oleh seluruh pelanggan sehinggan meningkatkan pelanggan loyal Indomaret.

3. Dalam menjalankan sistem baru sebaiknya tetap melakukan pemeliharaan sistem agar dapat digunakan dalam waktu lama.

\section{DAFTAR PUSTAKA}

[1] Al Fatta, Hanif. (2013). Analisis dan Perancangan Sistem Informasi. Yogyakarta: Andi.

[2] Ali, Hapzi dan Wangdra, Tonny. (2010). Sistem Informasi Bisnis "Si-Bis". Cetakan Pertama, Jakarta: Penerbit Baduose Media.

[3] Husda, Nur Elfi. (2012). Pengantar Teknologi Informasi. Cetakan Pertama. Penerbit Boduose. Jakarta.

[4] Hartono, Bambang. (2013). Sistem Informasi Manajemen Berbasis Komputer. Rineka Cipta, Jakarta.

[5] Jogiyanto, Hartono. (2010). Model Kesuksesan Sistem Teknologi Informasi. Yogyakarta: Andi Offset.

[6] Kadir, Abdul. (2014). Pengenalan Sistem Informasi. Edisi Revisi. Yogyakarta: Andi Offset.

[7] Rosa, A.S dan Salahuddin, M. (2011). Rekayasa Perangkat Lunak Terstruktur dan Berorientasi Objek. Informatika. Bandung.

[8] Sutabri, Tata. (2012). Konsep Dasar Informasi. Yogyakarta: Andi Offset.

[9] Sutarman. (2012). Pengantar Teknologi Informasi. Jakarta: Bumi Aksara.

[10] Turban, Efraim dan Volonino, Linda. (2010). Information Technology for Management. Edisi Ketujuh.

[11] Yakub. (2012). Pengantar Sistem Informasi. Yogyakarta: Graha Ilmu.

[12] php.net, "PHP: History of PHP - Manual." [Online]. Available: $\quad$ http://php.net/manual/en/history.php.php. [Accessed: 01-Juni-2017].

[13] Saputra, Agus. (2012). PHP, HTML5, dan CSS3. Jakarta: Jasakom.

[14] Husni Al Amin, I., \& A, K. (2014). Aplikasi CustomerRelationship Management (CRM) di Cv. Matahari Digital Printing Semarang. Dinamika Teknik, 8(2): 49-65.

[15] Januaris Kundre, A., Wisnubadhra, I., \& Suselo, T. (2013). Penerapan CustomerRelationship Management dengan Dukungan Teknologi Informasi Pada Po. Chelsy. Seminar Nasional Teknologi Informasi dan Multimedia, 28: 7-11.

[16] Milwandhari, S. (2011). Perancangan ECustomerRelationship Management Pada Perusahaan Bidang Jasa Perhotelan. SEMASSI, 1: 1-6

\section{BIODATA PENULIS}

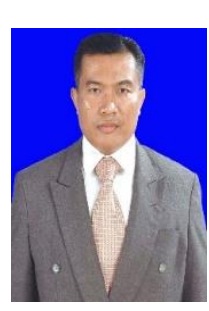

Tukino

Master of Information System Management, STMIK Putera Batam, Certified Cisco CCNA Instructor, Electrical Engineering and Information Technolgy Dept. Gadjah Mada University 2016, Lecturer of Computer Science at Putera Batam University, Batam. Email: mas.kino@gmail.com. 